\title{
Youth Employment Insecurity and Development in
}

\section{Nigeria}

DOI: https://doi.org/10.47175/rissj.v1i2.49

\section{| Ogunmefun Folorunsho Muyideen ${ }^{1, *}$ | Okuneye M. $\mathrm{Y}^{2}$ |}

\author{
${ }^{1}$ Department of Criminology \\ and Security Studies, Chrisland \\ University, Owode, Abeokuta, \\ Ogun State \\ ${ }^{2}$ Department of Accounting \\ and Banking/Finance, \\ Chrisland University, \\ Abeokuta, Ogun State
}

"folorunshoogunmefun@yahoo.con

\begin{abstract}
The alarming rate of employment crisis among the youths is one of the manifestations of insecurity in Nigeria which has negatively eaten deep into developmental project of Nigeria. Youths are generally considered as the bedrock, prime-mover and cornerstone for achieving progressive development in any nations, Once, youths are denied opportunity to gainful employment they easily turn to negative innovations that may be detrimental to nation development. Unemployment as a social milieu will negate socio-political, economic and educational development of the nation. However, average Nigerian goes to sleep at night with one eye closed while other opened which may lead to poor manpower development, physical harassment delinquency, criminal activities, psychological trauma as a result of civil unrest among others. Content systematic method of analysis was adopted in reviewing relevant publications from different search engines such as EMBASE, PDF, Scholarly Google, Scopus, JSTORS to supports the outcome of the inquiry. Social Contract Theory by Auguste Comte, Classical and neo-classical theories by Schumpeter, Boulding, were adopted to justify the causes, consequences and solutions to youths unemployment in Nigeria. On this ground, the following recommendations were made the Nigerian government, philanthropists and Nongovernmental organizations should learn more on the value associated with social contract as the main determinant of social development Also, more recreational vocational and formal learning centers should be institutionalized to make room for employment accessibility, flexibility and employability among youths for creativity among others.

KEYWORDS

Youth; unemployment; crisis; development; entrepreneurship
\end{abstract}

\section{INTRODUCTION}

Evidence gathered from several publications deciphers that employment crisis is a global menace that negate human developmental activities. Thus, the prevalence of crisis of employment in the world needs urgent attention of the government, philanthropist, nongovernmental organizations academia, researchers and other fields in tackling and provide practicable solutions to the menace of unemployment and other negating activities that might degenerated from the menace before it get out of control. In addition, employment crisis is a global discourse because the trend of unemployment is traceable to developing and developed countries (European States, United States of America, Africa Continent and Asia) among others But the measure or mechanism put in place to fight the menace by political elite or leaders differs in terms of strategies, approaches, monitoring, evaluating and prevention techniques. For example, literatures reviewed shows that due to acute 
financial crisis in 2008 and COVID-19, many people in the United States, European and other continent faced the menace of unemployment. However, European Union figures suggest that around one-in-five young people in Europe as at the time of the acute economic and financial crisis were unemployed in 2011 whilst unemployment in countries such as Greece and Spain was recorded at 40 per cent (Eurostat, 2011; World Bank Reports, 2020).

Table 1. The table below deciphers that statistics of current unemployment rate in the developed and developing countries in the world

\begin{tabular}{lll}
\hline SN & Countries or States with Unemployment Records & Percentages \\
\hline A & Developing Countries & $\begin{array}{l}\text { Unemployment } \\
\text { Records }\end{array}$ \\
\hline 1 & Namibia & $20.3 \%$ \\
2 & South Africa & $28.2 \%$ \\
3 & Botswana & $18.2 \%$ \\
4 & Angola & $6.9 \%$ \\
5 & Kenya & $2.6 \%$ \\
6 & Nigeria & $23.9 \%$ \\
7 & Ethiopia & $2.1 \%$ \\
8 & Ghana & $4.3 \%$ \\
9 & Burkina-faso & $6.3 \%$ \\
10 & Mali & $7.2 \%$ \\
11 & Cameroun & 3.4 \\
\hline B & Developed Countries & Unemployment \\
& & Records \\
\hline 12 & USA & $3.7 \%$ \\
13 & Spain & $14.02 \%$ \\
14 & UK & $3.9 \%$ \\
15 & Denmark & $4.7 \%$ \\
16 & Croatia & $6.9 \%$ \\
17 & Canada & $5.6 \%$ \\
18 & Brazil & $12.1 \%$ \\
19 & China & $4.3 \%$ \\
20 & Germany & $3.0 \%$ \\
21 & Russia & $4.6 \%$ \\
22 & Israel & $3.9 \%$ \\
\hline
\end{tabular}

Source: World Bank Reports, 2020

Unemployment statistics derived from International Labour Organisation (ILO, 2017) avers that the number of unemployed persons in Sub-Saharan Africa increased from 28 million in 2016 to 29 million in 2017. More so, the rate of youth unemployment stands at $7.2 \%$ for the region which makes it one of the worse cases of unemployment in the world) Furthermore in Nigeria, the rate of unemployment among the youths increased from $14.2 \%$ in the $4^{\text {th }}$ quarter of 2016 to $16.2 \%$ and $18.8 \%$ of the $2^{\text {nd }}$ and $3^{\text {rd }}$ quarter of 2017 respectively which have negatively affected the growth and development of the youth population (NBS, 2017). The statistic revealed by the National Bureau of Statistics (2019), asserts that unemployment rate among the youths decreased from $38 \%$ in the $2^{\text {nd }}$ quarter of 2018 to $36.50 \%$ in the $3^{\text {rd }}$ quarter of 2018 , It is important to note that the figures above may not have clear picture or total statistics of the youth unemployment and poverty rates in Nigeria, however, the result reveals by the Newspaper Organization is pointing to futuristic problems in the country which may obstruct developmental activities. Therefore, there is a 
need for something collectively urgent to be done so that the problem will not remain a generational problem in the country.

In Nigeria, according to Ojo (1998), there are five categories of unemployment in the country which either promote or demote developmental activities based on the method of practical and empirical application.

Table 2. The table below shows categorization of unemployment into five stages in Nigeria

\begin{tabular}{|c|c|c|}
\hline $\mathbf{S} / \mathbf{N}$ & Types of Unemployment & Meaning of Unemployment \\
\hline $\mathbf{1}$ & Structural Unemployment & $\begin{array}{l}\text { This is the type of unemployment whereby the } \\
\text { qualifications of a person is not adequate or meets the } \\
\text { responsibilities of the job assignment. Unemployment } \\
\text { may arise as a result of certain factors such as } \\
\text { technological displacement, lack of proper skills, } \\
\text { changes in the structure of the wages }\end{array}$ \\
\hline 2 & Frictional Unemployment & $\begin{array}{l}\text { The frictional unemployment occurs when an } \\
\text { individuals or person is out of one job and he or she } \\
\text { is in search of another one. The time the person is } \\
\text { staying without jobs is frictional unemployment } \\
\text { which may be long or short. The major Cause of } \\
\text { frictional unemployment is normal labour turnover }\end{array}$ \\
\hline 3 & Cyclical Unemployment & $\begin{array}{l}\text { This is the type of unemployment that is caused by } \\
\text { change in business conditions or during recessions } \\
\text { and depression. In other word, cyclical } \\
\text { unemployment occurs due to disequilibrium that } \\
\text { leads to insufficient aggregate demand to purchase } \\
\text { full employment output in a country }\end{array}$ \\
\hline 4 & Seasonal Unemployment & $\begin{array}{l}\text { This kind of unemployment is based on the dictate of } \\
\text { the season. Seasonal unemployment comes and goes } \\
\text { with the seasons of the year that dictate the demand } \\
\text { of certain jobs. Examples Demand for Agricultural } \\
\text { jobs }\end{array}$ \\
\hline 5 & Residual Unemployment & $\begin{array}{l}\text { This type of unemployment occurs to people who are } \\
\text { physically or mentally disabled that makes them to } \\
\text { have low level of productivity, if at all any } \\
\text { opportunity is open to them. }\end{array}$ \\
\hline
\end{tabular}

Source; Ojo (1998)

Likewise, Oyebade (2003), avers that the categorization of unemployment in Nigeria is very difficult to measurement, because problem of accuracy, accessibility and achievement. However, he grouped Nigeria's unemployment into two (2) categories. The first category are the older unemployed people that lost their jobs through retrenchment, redundancy, or bankruptcy while the second category are the younger unemployed people who had never have access to employment opportunities. Awogbenle and Iwuamadi (2010) were more concerned about population issues in Nigeria where they stated that Nigeria has a youth population of 80 million, representing $60 \%$ of the total population of the country. Although, statistic shows that 64 million of these youths are unemployed, while 16 million are under-employed. The statistic derived from the stated scholars justify what the country (Nigerian) should be expecting from the youths in the future.

The importance of youths in developmental activities cannot be underrated because of their potential endowment or characteristics but in African continent reverse has been the case ever), Large number of countries in Africa continent were faced with high rate of 
employment (Onited Nations, 2016, World Bank Reports, 2020) These problems play a key role in the under-development of the continent; however, one can conclude that Nigeria's unemployment poses as threat to its development, security and peaceful coexistence of the diverse entities in the country (Unegbu, 2011). For example, Ajufor (2013) laments that youths in Africa hold great potential as drivers for economic growth through participation in labour market. Also, the youths are the resource which leads to innovation that supports the achievement of good governance and political reforms. Also, Casey (2013) argues that increase in unemployment among the youths will degenerate to other social problems which will affect the psyche of the people and infringe on people's ability to develop entrepreneurship skills and intellectualism Furthermore, the reports of unemployment statistics in Nigeria shows that increase in unemployment rate among the Nigerian youths plays a negative role in the developmental process of the country. It is true that when the youth are faced with problem of unemployment despite the level of their family background, educational aspiration and qualification, marital status, ethnic and religious background, they will turn to alternative means open to them for achieving success without looking at the future consequences associated with criminal sanctions. It on this regards the following research questions were set to guide the outcome of the research inquiry. However, the paper try to examine predisposing factor that leads to employment crisis among youths in Nigeria, more so, the effect of unemployment of industrial and economic development of Nigeria, strategies put in place to combat youth unemployment in Nigeria so as to provide solutions to the menace that negate Nigeria Development.

\section{REVIEW OF LITERATURE}

In 2010 the then former Lagos State Commissioner of Police (Mr. Marvel, Akpoyibo) in a "Report on Youth and Policing Summit in Lagos State and the National Confab reports in 2014 acknowledged and confirmed that the most important group in any society are the youths. This is because the youths are considered as building block of any development process in any country, but in Nigeria, the youths constitute the highest percentage of victims of crime profile in Lagos State. The reason for this is not farfetched because youths are considered as vibrant group with very active intellectual and physical abilities to contribute towards achieving progressive societal development in any country. Unfortunately, if the opportunities to positively express such potentials are limited, they (youths) can easily turn to negative opportunities open to them for survival.

Nayak, (2012), comments that one of the greatest social problems facing socioeconomic and political development in the 21st century among the third world nations, precisely Nigeria is the menace of youth unemployment which has resulted into negative innovation such as armed robbery, car snatching, kidnapping, cybercrimes (yahoo-yahoo ) riot, cultism, militancy, ethno-religious crises, burglaries, rape, murder, forgery, larceny and shoplifting among others However, the menace has affect the nation and international image of the citizens and the entire country at large because Nigeria was rated as the third most corrupts country in the world.)Transparent International, 2011) behind Colombia and Haiti.

\section{Tripartite Notion of Social Contract Theory}

Social contact theory is attributed to several scholars namely Thomas Hobbes, John Locke, Emile Durkheim, Frederick Hegel, Karl Marx and Auguste Comte among others. But the theory of tripartite notion of social contract is a variant of social contract theory attributed to the work of Auguste Comte. The fundamental postulation of Auguste Comte social 
contract is that semblance of orderliness in any society is anchored on the three units of analysis in the state that must performed their historical responsibility or functions, however, the functions of the three selected units of analysis will determine level of development that will be obtainable in the country either progressive of retrogressive development The units of analyses in the state that must performed this functions are the state and its agents, the capitalists and the citizens.

\section{The State and Its Agents}

In any society or state, the law of social contract asserts that it is the duty and responsibility of the state government such as the legislation, the executive, judiciary, co-ersives security apparatus and the media to enact, implement and interpret public oriented rules, regulations and laws in order to ameliorate and foster peaceful coexistence among the populace or improve the living conditions of the people socially, politically, educationally, economically and psychologically among others. This means that in Nigeria, it is the duty and responsibility of the state and its agents to provide quality security to lives and properties, creation of adequate employment opportunities, creative and qualitative education and educational policies for the masses, creation of good roads, transportation system, health care facilities, and good housing system among others. In Nigeria creation of employment for both the youths and old people is the responsibility of the state government at all levels both at state, federal and local government levels.

\section{The Ministries in the State and Capitalists/Philanthropists}

The ministers are the appointed governmental agency that acts as a link or bridge between the government and citizens in discharging their historical responsibility. It is perceived that the laws or policies formulated at the federal levels on either education, economic, works, commerce, power, housing and industries can only get to the citizens through the various ministries established to monitors and evaluates the programs schedule by the government. More so, the ministers cannot do it alone they needs to invite the capitalists and philanthropists that will champion the contract in order to create enabling society that will foster create thinking towards achieving positive human societal development.

\section{The Citizens in the State}

The citizens are the member of the society that submitted their sovereign right to elects the individuals or group of people that will represents their interest in national developmental issues in Nigeria. The fundamental responsibility of the citizens is to pay taxes regularly and obeys national calls at any time they are needed to represent the image of the country. If all the units mentioned perform their historical functions based on the valued social contract, it will bring about semblance of orderliness in the society that will later turn to enhancement in the living standard of the people in the country. But if any of the part or unit fails to perform its historical responsibility especially on the part of the government it will lead the society towards emanate contradiction of under development or Anomie in the state. ( Ninalowo, 2008).

This social contract theorist believes that in any country to include Nigeria, it is the sole responsibility of the state government to create enabling environment and employment opportunities for the youths so as to create a crime free society. In addition, political System of Entrepreneurship is propounded by Boulding (1917) supported the ideology of Auguste Comte on Tripartite Notion of Social contract, According to Boulding's political system of entrepreneurship growth also argued that the political institution is the only institution that can create adequate infrastructure, favorable laws, favorable taxation 
system and procedures, provide incentives and subsides, security to entrepreneurs, create promoting policies and can encourage people towards entrepreneurship development in any country. More so, Government can also build supporting system for potential entrepreneurs. Thus, the commitment of political system can contribute significantly towards entrepreneurial development.

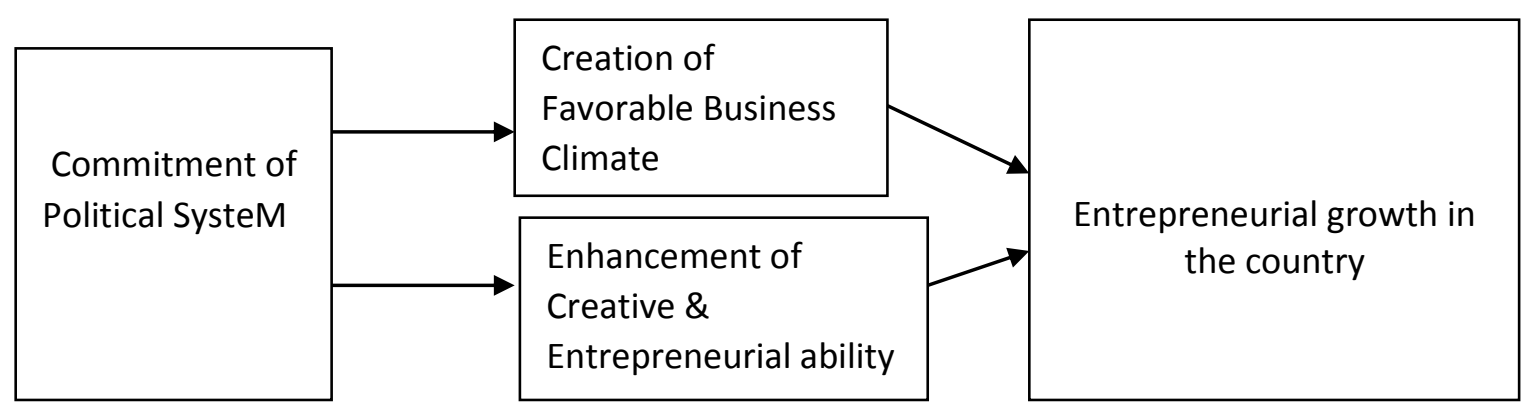

Figure 1. The figure above is anchored on Boulding's Political System Theory of Entrepreneurship

According to Acs and Naude (2013), one of the clear responsibility of a state and its functionaries is centered on how the mentioned agencies or units must be willing to address market failure that plagues entrepreneurial start up and innovation activities in any country facing economic problem They stressed further that entrepreneurship policy or policies enacted in Nigeria should be towards enhancing the developmental impact of entrepreneurship or improve the quality and allocation of entrepreneurial ability. More so, progressive improvement in the quality of entrepreneurial ability must not only be on the improvement of the skills and education of entrepreneurs but focus should be more on the improvement of the innovative abilities of the entrepreneurs in the country. This is because the innovative entrepreneurship is the most desirable for achieving societal growth and development.

\section{RESEARCH METHODS}

The method adopted for the research inquiry is anchored on the use of Content systematic analysis method for reviewing secondary data or information to support the success of the theoretical discourse. The method (Content Systematic Analysis method will help the researcher to review scholarly publications that shed rational meaning to the peer review literatures articulated such as journals, articles, textbooks, and magazines, newspapers reports. The secondary data were searched and collected from different search engines

Table 3. The table below is centered on the analysis of the several articles reviewed as secondary sources to support the justification of the outcome of the research inquiry

\begin{tabular}{clcl}
\hline S/N & Publications & Number & Search Engines \\
\hline 1 & Journals & 2 & Scholarly Google \\
& & 8 & Sociological Abstract \\
& & 1 & Psychological Abstract \\
& & 5 & Scopus \\
\hline 2 & Article & 2 & EMBASE \\
& & 13 & National Bureau of Statistics \\
& & & National Population Commission \\
& & & United Nations Reports \\
& & & World Health Organizations \\
\hline
\end{tabular}




\begin{tabular}{llll}
\hline 3 & Textbooks & 14 & National and International Books \\
\hline 4 & Newspaper/Magazines & 9 & Daily Times \\
& & This Day Newspaper \\
& & Daily Trust \\
& & Vanguard \\
& & The Punch Newspaper \\
\hline $5 \quad$ Catalogues & 1 & CLEEN Foundation Reports \\
\hline Researcher Concept 2020 & &
\end{tabular}

\section{RESULT AND DISCUSSION}

The word development connotes different meaning to different people at different stages of lives. But the centrality of the word is that it is anchored on enhancement of human living condition or standards socially, politically, psychologically, educationally and economically This statement was asserted by Ninalowo, (2010); and Oyekanmi and Soyombo,( 2015). It is arguable that it is possible that economic growth may not really allow for progressive human development if the leaders choose to be animalistic rather than being humanistic in their approaches towards promoting positive human conditions. According to Onyeneho \& Ezeano (2011) development is a process by which individuals or groups of people in a community or country improve the state economic, political and social wellbeing of the populace. Likewise, Amos (2010) and Oyeshola (2008) define development as a pattern of resource use that aims at addressing human needs while preserving the environment so that these needs can be met not only in the present but also for generation to come. Therefore it is of great importance to know that for any political and economy institutions to be recognized it must be able to provide employment opportunities for the youths and create conducive atmospheric conditions such as regulating and enacting policies that will be public friendly to supports entrepreneurship activities in the country

In addition, adequate provisions of human basic need are very crucial in the survival of mankind in any parts of the world. These basic needs according to Abraham Maslow hierarchy of needs entail having constant access to food supply, housing, clothing, health, education industrial and agricultural development, preservation and protection of the environment to enable people to live a comfortable life and enjoy reasons for being a citizen of the country (Nigeria). It is pertinent to note that millions of Nigeria youths struggle on daily basis looking for how to survive without any forms of supports or having access to loans to jump start entrepreneurial jobs. However, Agbeze (2012) explains that entrepreneurial skills and potentials can only be possible and achievable in any country when the citizens enjoy comfortable policies enacted in the state In Nigeria, there are several organizations established in Nigeria to monitor and evaluate entrepreneurship skill development in the past and present some of these organizations are stated below

Bank of Industry (BOI) b) Small and Medium Enterprises Development Agency of Nigeria (SMEDAN), c) Small and Medium Industries Equity Investment Scheme (SMIEIS), d) National Directorate of Employment (NDE) e) Global Entrepreneurship Monitor (GEM) f) Subsidy Re-Investment and Employment Program (SURE-P) among others g) Lagos State Development Trust Funds h) Micro, Small and Medium Enterprises i) 7 points Agenda for Economic Development j) Palliative Measure among others. More so, Nigerian government's endorsement and support some multilateral agencies to give loans to small and medium scale entrepreneurs in the country. Thus, few of the agencies are a) European Investment Bank (EIB) b) Guarantee Scheme for loans to Small and Medium Enterprises c) Enterprise Creation Fund (ECF) for Small Scale Enterprises d) African Development Bank (ADB) among others not mentioned But despite all these 
Terzungwe (2013) laments that despite the fact that many institutions were established to fight unemployment in Nigeria; the country is still faced with numerous social milieus as a result of the inability of government and the private sector to create jobs for the youths and adults in the country. He stressed further that most of the attempts made by the Nigerian government to introduce programs to fight or reduce poverty and create employment opportunities have not yielded the desired result. Thus, most of the strategies and plans put in place by the Nigerian government and the multi-national agencies to fight the menace of youth's unemployment in the past as only yielded little or no progress in the area of creating or generating adequate employment opportunities for the youths but further created barriers. Thus, the barriers created negate the entrepreneurship developmental activities of the country

Also, Adesina (2013) avers that there are over 800 collapsed industries in Nigeria and over (37) thirty-seven factories closed shops in 2009. About half of the remaining operating firms have been classified by Manufacturers Association of Nigeria (MAN) as ailing situation that poses a great threat to the survival of manufacturing companies in the Country due to several conditions such as epilepsy electrical power supply, war, harsh governmental policies, ethnic or religious crisis among others. For example large number of Nigerian youths who are unemployed are capable of undermining democratic practice as they constitute a serious threat to the nation if engaged by the political class for destruction (Olatunji and Abioye, 2011; Okafor, 2011) More so, Okafor, (2011) in a survey carried out as part of its membership operational audit in January 2010 by the Manufacturers Association of Nigeria (MAN), The survey covers five major manufacturing zones in Nigeria such as Lagos, Northern Central, South-East, South-West and South-South Zones.

Table 4. The table below decipher the companies that shut down services or productions in Nigeria

\begin{tabular}{lll}
\hline S/N & Result of companies that shut down operation in 2009 in Nigeria & $\begin{array}{l}\text { Total } \\
\text { Estimate }\end{array}$ \\
\hline 1 & $\begin{array}{l}\text { Total of companies that shut down operation in Nigeria } \\
\text { Number of firms that became terminally and collapse in Northern } \\
\text { area comprises of Kano and Kaduna manufacturing axis }\end{array}$ & 176 \\
3 & $\begin{array}{l}\text { Number of firms that shut down operation in South-East in Nigeria } \\
\text { comprises of Anambra, Enugu, Imo, and Abia }\end{array}$ & 178 \\
4 & $\begin{array}{l}\text { Number of firms that shut down operation in South-South in Nigeria } \\
\text { comprises of River, Cross-River, Akwa-Ibom }\end{array}$ & 46 \\
5 & $\begin{array}{l}\text { Number of firms that shut down operation in South-West which } \\
\text { comprises of Ogun, Lagos, Ondo, Ekiti, Osun, Kogi and Kwara }\end{array}$ & 225 \\
6 & $\begin{array}{l}\text { Number of firms that shut down operation in Lagos State comprises } \\
\text { of some industrial avenue such as Ikeja, Apapa and Ikorodu among } \\
\text { others }\end{array}$ & 214 \\
\hline
\end{tabular}

Source: Manufacturing Association of Nigeria (2011)

As a result of shut down of manufacturing industries in Nigeria, employment crisis increases leading to job insecurity in the country (Nigeria). In Nigeria today, millions of Nigerian youths roam on the streets daily in search of employment opportunities. Although, most of them (the youths) on the streets are between school age and should be in school acquiring formal or vocational education that will transform their lifestyles and the society at large. But, due to the state of unemployment crisis in the country, most of the Nigeria youths) prefers to innovate or engage in highways hawking business such as water, 
loaves of bread, phone accessories, plantain chips, bananas and oranges yogurt, video cassette and working as a conductors in the garage for survival (Igbo, 2011).

Studies in the past have shown that the implications of unemployment on Nigeria's socio-political and economic development cannot be overemphasized because it has affected the growth and development process of the country politically, economically, educationally, psychologically and socially. This is because unemployment has left much to be desired as far as development in Nigeria is concerned. One of the obvious implications of unemployment in Nigeria is poverty that is fundamental to Millennium Development Goals (MDGs). Poverty is a serious problem that has a lot of implications on the lives of individual's families and nations. The United Nations Reports (2014) posits that average Nigerians lived below US\$1.25 dollar daily. The implication of these shows that underemployed persons and unemployed youth cannot meet the basic needs for survival however, if these persists it means that the lives of the people are not guaranteed in the country. In addition, Sanni (2013) observed that: when unemployment persists in any country it will negate development. For example most of the criminal activities or actions carried out in Niger/Delta area of Nigeria such as the disruption of oil production, pipeline vandalism and associated crimes were done by a well-known youth's gang in the area known as Movement for the Emancipation of Niger Delta (MEND). Thus, the reasons put forward for the justification of the fighting and struggle is centered on resource control in the area by the state governor not by the federal government. Due to these struggle and fight for state control of state resources by the group (MEND) Nigeria lost $\$ 15.8$ billion revenue that would have added impetus to Nigeria's development. Production could not continue because the pipelines were vandalized or destroyed aside the number of people that died while struggling to siphon oil from broken pipes. (Dalhatu, 2012). Presidents Mohammed Buhari is of the view that the militants needs to be trained so that peace will be restored back in the area and this can be done through the concept of entrepreneurship skills and intellectualism development.

The development of businesses may contributed to the growth of the Nigerian economy since scholars such as (Obi et al., 2018; Orugun and Nafiu, 2014) have argued that enterprises constitutes $90 \%$ of the industrial sector in enterprise and $70 \%$ of the national industrial development (Yunusa and Paul, 2018).Since Opafunso and Adepoju, (2014) have argued that small scale enterprises' contributions to the nation's GDP and exportation at 2013 stood at $48.47 \%$ and $7.27 \%$ respectively. With respect to the contributions of goods derived from entrepreneurship, Opafunso and Adepoju, (2014) argue that Nigeria has been smoothening her balance of payment deficit through foreign exchange generation In every act of entrepreneurship development, a new vision, ideas, innovation, strategies are developed through creative thinking rather than depending on how the Nigerian government will contribute towards entrepreneurship growth and development. In Nigeria and everywhere, entrepreneurship development is all about the creation of various small and medium enterprises by various individuals whom, if not employed, becomes selfemployed automatically and usually ends up an employer of labor.

\section{CONCLUSION}

In Nigeria despite the fact that adoption of entrepreneurship skills development is to bring about positive improvement in the country if properly adopted into the Nigerian developmental projects. Onwubiko (2011) asserts that there are barriers that limit the success of entrepreneurship skills and potential development in Nigeria. 1) Absence of Infrastructural Facilities 2) Lack of Adequate Training and Poor Educational Policy or Policies 3) Bad Governance and Poor Budgetary Allocation 4) Cultural Factor 5) 
Constrained access to Local and International Markets 6) Inadequate or Lack of access to Finance 7) Lack of Supports from Enterprises Institutions in Nigeria.

In conclusion, the rate at which youth unemployment negate Nigeria development is on increase because most Nigerian leaders are not ready to show interest in the fight against the menace. It is generally believed that the youths are the future leaders of tomorrow and today, It is said that whatever they experienced today will determine their tomorrow. The productive years of many youths in Nigeria are preciously wasted and what can they do that will not turn to war? The leaders are not even looking into what they can do to aid or create employment opportunities for the youths in Nigeria rather they are more interested in how to embezzle Nigerian currency for their own personal development or vested interest. Dudley Seers laments that development is not about the number of infrastructural facilities and amenities created but how many of the infrastructural facilities and amenities are enjoyable by human being as at the time it was established in the society. Therefore, entrepreneurship skills and intellectual development should not just be approach from mental perspective alone but it should be grounded on practical perspectives among all societal members because development should be the watchword for all.

In Nigeria, the youths are faced with lack of creativity or properties for achieving entrepreneurship development. Therefore, the collective efforts of the entire Enabler, Activists, Brokers and Advocate should come together and discover the potential youths in the study locations based on their professional experience. The Enablers are the people that will discover the talents, the Brokers are the people that will linked them with the materials available to them in the location, The Advocate are the people that will make their needs to be known to the government that ill leads or linked them while the Activists are the body that will fight for the rights of the youths whenever they are deprived of their rights. It is believed that youth entrepreneurial skills can be achieved when the societal laws, values, norms and policies are favorable to the citizens but others scholars believed that it withdrawal of status respects accords to the unrealistic leaders in Nigeria that can make millions of the Nigerian youths to think of what they do that will bring out entrepreneurial skill and development in them.

To make a difference, Nigerian governments must take practical steps. What is required is not rhetoric, not bureaucracy. The way forward is that the Nigerian government must encourage the youths to be self-employment through creation of enabling environment for business and investment opportunities for entrepreneurs, to resolve the country's energy crisis though it has privatized the sector they must make it a their priority.

The Philanthropist, NGOs and international bodies should seeks on how to help improve youth livelihoods through the pursuit of empowerment objective by tapping into the dynamism of young people and build on their strong sprit of risk-taking through entrepreneurship development, This is as a result of involvement in corporate social responsibility in any country.

Creation of vocational and technical education as well as practical and theoretical knowledge on entrepreneurial development schemes needs to be properly applied to Nigerian economy development. This is because vocational, technical and entrepreneur education are powerful tools that could empower the youth to be self-employed.

There is also a needs for creation and proper monitoring of the creational facilities such football field in every local government so that the youth energy packed that cannot be fully demonstrated can be channeled to sporting activities.

Neglect of agricultural activities such as farming fishing and hunting has equally contributed to no small measure to Nigeria's unemployment. Therefore the Agricultural 
sector needs to be totally revived in the country rather than over concentrating on the oil sector.

Every Nigerian must be ready to fight or tackle corruption that has cut across all the levels or strata of government in Nigeria. This is because the money that are supposed to invent in the development of entrepreneurial skills development in Nigeria are diverted to their personal account which will negate Nigerian development.

The youth must purged themselves out of preconceived notions and be ready to create an atmospheric conditions for themselves that will bring out the potentials and skills in them towards nation building.

\section{REFERENCES}

Acs, Z. J and Naude, W.A (2013), Entrepreneurships, Stages of Development and Industrialization. Oxford. Oxford University Press

Adesina, O.S (2013)“Unemployment and Security Challenges in Nigeria. International Journal of Humanities and Social Sciences. Vol 3(7) pp146-156

Agbeze C (2012) Entrepreneurship: The need to create wealth. Why Not now. Ohafia This Day Newspaper 14 February 2012.

Ajufor B (2013), Challenges of Youths Unemployment in Nigeria; Effective Career Guidance as a Panacea. African Resource Revision, 7(1)307-321

Amos, A.J. (2010). 'Corruption and the Challenges of Sustainable Development in Nigeria'. Kwara State University Journal of Social Sciences, 2(1)10-13.

Anyadike A.A (2012).Entrepreneurship Development and Employment Generation in Nigeria: Problems and Prospects. Journal of Education. \& General Studies. 1(4):88-122

Awogbenle A.C and Iwuamadi K.C (2010). Youth Unemployment: Entrepreneurship Development Programme as an Intervention Mechanism. African Journal of Business. Management .4(6):831-835.

Bula A.L (2012a) Performance of women Entrepreneurs in Small Scale Enterprises (SSEs): Marital and Family Characteristics .iiste Publication 4(7)

Bureau of Labour Statistics, (2018). The Rate of Unemployment in Nigeria.Available on https://nigerianstat.gov.ng/elibrary?queries[search]=Prison\%20statistics Retrieved on Dec. 13, 2018

Casey, J (2010), Implementing Community Policing in Different Countries and Cultures. Pakistan Journal of Criminology. 2(4), 55-70

Central Intelligence Agency (2018). Country Comparison: Unemployment Rate. Available on <https://www.indexmundi.com/g/r.aspx?c=ni\&v=74> Retrieved on Dec, 12, 2018

Daily Trust (2013). 'Jonathan: Unemployment Can Cause Us Serious Problems'. Oct, 18

Daily Trust, (2013) 'Senator Urges Youth to Embrace Agriculture'. September 12

Dalhatu D.D. (2012). Cause and Effects of Conflict on Nigeria's Development. MultiDisciplinary Journal of Research and Development Perspective 1(2), 2-6

De Clercq D and Honig B. (2011), Entrepreneurship as an integrating mechanism for disadvantaged Persons. Entrepreneurship and Regional Development 23: 353-372.

Enterprise Support' CSME Working Papers, Number 87, Coventry: University of Warwick.

Eurostat (2011) Unemployment rate, annual average, by sex and age groups (\%), http://appsso.eurostat.ec.europa.eu/nui/setupModifyTableLayout.do

Giacomin, O., Frank, J., Guyot, J. L \& Lohest. O. (2011). Opportunity and/or necessity entrepreneurship? The impact of the socio-economic characteristics of entrepreneurs https://www.researchgate.net/publication/50380284_Opportunity_andor_necessity_en trepre

Greene, F.J. (2008) 'Youth Entrepreneurship: Latent Entrepreneurship, Market Failure and Environment Planning. Journal of Government \& Policy, 27:2, 216-229 
Greene, F.J. (2009) 'Evaluating Youth Entrepreneurship: the Case of the Prince's Trust; Venture Creation by Young People. Entrepreneurship and Regional Development, 16:2,145-159

Hausmann, R and Rodrik, D (2003), Economic Development as Self Discovery. Journal of Development Economics 72(2),603-633

Igbo, E. U. M. (2011), Introduction to Criminology, Nsukka: University of Nigeria Press

National Bureau of Statistics. (2014) Statistical News: Labor Force Statistics No. 476. Abuja: The NBS

Isaacs E, Visser K, Friedrich C, Brijlal P (2007). Entrepreneurship education and training at the Further Education and Training (FET) level in South Africa. South Afr. J. Edu., 27: 613-629.

National Bureau of Statistics (2013). 'Nigeria's High Rate of Unemployment'. Retrieved February, $22^{\text {nd }}$ from www.thisdaylive.com $>$ Home $>$ NEWS.

National Population Commission, (2013). Unemployment in Nigeria Worsened Under Jonathan Government. Premium Times $11^{\text {th }}$ October.

National Bureau of Statistics (2017). The Nigerian statistical fact sheet on economic and social development. Abuja: National Bureau of Statistics.

National Bureau of Statistics (2019). The Nigerian statistical fact sheet on economic and social development. Abuja: National Bureau of Statistics

Nayak, R.C., (2012), Job Challenges and Coping Strategies of Women Police in Orissa: A sociological study in the Twin City of Cuttack and Bhubaneswar, Ph.D Thesis submitted to Utkal University, Bhubaneswar, Onisha.

Ninalowo, A (2008), Essays on the States and Civil Society. Lagos. First Academic Publications Limited

Nwokwu, M. (2013). 'The Effects of Youth Unemployment and Its Implications on SocioEconomic Stability of Nigerian Democracy'. Retrieved February, 21 ${ }^{\text {st }}$ from www.crimspace.com/profiles/blogs/th

Obi, J., Ibidunni, A. S., Tolulope, A., Olokundun, M. A., Amaihian, A. B., Borisade T. T and Peter, F.(2018). Contribution of Small and Medium Enterprises to economic Development: Evidence from a Transiting economy. Data In brief, 18: 835-839

OECD (2011), Entrepreneurship at a Glance 2011, OECD: Paris

Olokundun, M., Falola, H., Ibidunni, S. and Inelo, F. (2014). An assessment of the taught entrepreneurship program in Nigerian secondary schools. Merit Research Journal of Education and Review, 2(11): 257-275.

Ojo, F. (1998) Human Resource Management: Theory and Practice. Lagos: Panaf Publishing Inc.

Olaiya, S.A. (2013). 'Towards Vision 20:2020: Need for Attitudinal Change Emphasis on Youth Unemployment'. African Journal of Stability and Development. Afe Babalola University, Ado-Ekiti.

Okafor E.E (2011) Youth Unemployment and Implications for Stability of Democracy in Nigeria. Journal of $\quad$ Sustainable Development in Africa. Vol. 13(1) 13-43

Onwubiko CM (2011). Entrepreneurship and leadership; Nigeria and the Imperative for Youth Entrepreneurial Development. Journal of Entrepreneurial skills and Development 2(12):17-22.

Onyeneho E.E. and Ezeano.V.N (2011) Entrepreneurship: A Fundamental Approach. Enugu, John Jacob's Classic Publisher Ltd.

Orugun, J. J \& Nafiu, A. T. (2014). An Exploratory Study of Igbo Entrepreneurial Activity and Business Success in Nigeria as the Panacea for Economic Growth and Development. International Journal of Scientific \& Technology Research, 3(9):158-165 
Oyebade, S.A. (2003). Education and Unemployment of Youths in Nigeria: Causes, Impacts and Suggestions. National Economic Empowerment Development Strategy (NEEDS) Document. p.94.

Oyeshola, O.P. (2008) Sustainable Development: Issues and Challenges for Nigeria Ibadan: Daily Graphic Nig.

Ltd

Raimi L, A I (2010): Using Entrepreneurship Development and Corporate Social Responsibility as Strategies for Conflict Resolution Abuja. Nigeria

Report of Youth and Policing Summit in Lagos State (2010), Lagos. CLEEN Foundation. Support, OECD: Paris

Ritzer, G. (2012), Modern Theories in Sociology. London. McGraw-Hill Publications Limited

Saanu, G.D. (2013). Unemployment in Nigeria. Nigerian Tribune August, $1^{\text {st }}$ Retrieved February $21^{\text {st }}$ from www.tribune.com.ng/news2013/indexP.

Schumpeter, J (1949).Economic Theory and Entrepreneurial History. Cambridge: Harvard University Press, New Brunswick: Transaction Publishers.

Schumpeter, J (1983). The Theory of Economic Development: An Inquiry into Profits, Capital,Credit, Interest, and the Business Cycle.. New Brunswick: Transaction Books

Tergungwe, S. (2013). Surviving Unemployment. Daily Trust, $11^{\text {th }}$ October.

Ubochi, T. (2013). Unemployment in Nigeria. Retrieved November, $21^{\text {st }}$ nigeriaworld.com/11/092813.html.

Unegbu O (2011). Addressing youth unemployment in Nigeria. http://www.businessdayonline.com

United Nations Development Reports (2010). We can end Poverty: Millennium Development Reports. New-York. .

Utomi, P. (2011). Betraying the mission of the generation. The Guardian, Friday, 04 February.

Vanguard Newspaper (2013) Gunmen killed 42 in Yobe School Attack, June $6^{\text {th }}$

World Bank Reports (2012), The World's Youth; Adolescence in eight regions of the globe, New-York. Cambridge University Press.

World Bank (2013) Nigeria's High Rate of Unemployment. Retrieved November $21^{\text {st }}$ from www.thidaylive.com $>$ Home/NEWS.

World Bank Reports. (2013). Country and lending groups. Retrieved from http://data.worldbank.org/about/country-classifications/country-and-lending-groups

World Bank Reports (2020),Unemployment ; total (\% of total labour force) Modelled ILO estimate world unemployment rate. Worldbank.org /indicator/SLUEM-25?/locations.26 World Bank. Washington DC

World Health Organization Reports (2012), Skills Development in the informal Sector of Sub-Saharan Africa. World Bank. Washington DC

Yunusa, A and Paul, A. A. (2018). Assessment of the Contributions of Small-Scale Enterprises to the Development of the Nigerian Economy. Journal of Good Governance and Sustainable Development in Africa (JGGSDA), 4(1):3747thttp://www.rcmss.com/index.php/ijpamr;www.academix.ng 